\title{
O papel das DNA polimerases propensas a erro e da atividade das uracila DNA glicosilases na mutagênese espontânea em Caulobacter crescentus
}

Dissertação apresentada ao Programa de Pós-Graduação em Microbiologia do Instituto de Ciências Biomédicas da Universidade de São Paulo para obtenção do Título de Mestre em ciências.

Area de concentração:

Microbiologia

Orientador: Prof. Dr. Rodrigo da Silva Galhardo

Versão corrigida. Versão orginal electrônica, encontra-se disponível tanto na Biblioteca do ICB quanto na Biblioteca Digital de Teses e Dissertações da USP (BDTD). 


\section{RESUMO}

Valencia, AO. O papel das DNA polimerases propensas a erro e da atividade das uracila DNA glicosilases na mutagênese espontânea em Caulobacter crescentus. [Dissertação (Mestrado em Microbiologia) ]. São Paulo: Instituto de Ciências Biomédicas, Universidade de São Paulo; 2017

Neste trabalho desvendamos o papel das DNA polimerases dinB e dnaE2 em $C$. crescentus na mutagênese espontânea usando dois marcadores moleculares xyl-bla e Cltet. Observamos que as taxas de mutação dos marcadores não variam significativamente entre $\operatorname{din} B$, dnaE2 e parental, coincidindo com os resultados prévios com o gene rpoB. As trocas de bases, tanto no gene $c l$, como em $x y / R$, há um predomínio de mutações $\mathrm{AT} \rightarrow \mathrm{CG}$, como observado em rpoB, e diferente da região $P x y / X$ em xyl-bla. $O$ gene $x y / R$ apresenta um hotspot que promove a inserção de uma citosina após a base 230. Neste marcador observamos que a presença de pequenas deleções (frameshifts-1) de uma base na cepa selvagem e dnaE2. Esse tipo de mutação não está presente na linhagem $\operatorname{din} B$. Esses resultados sugerem um papel importante de $\operatorname{din} B$ na formação de deleções (frameshifts-1) in vivo em C. crescentus. Também observou-se que 0 agente 4-NQO não induz mutagênese em $C$. crescentus, ao contrário de $E$. coli. Também observamos pouca eficiência da atividade de uracila glicosilase em $C$. crescentus quando comparada com E. coli.

Palavras- Chave: $C$. crescentus. mutagênese espontânea. DNA polimerases. 


\section{ABSTRACT}

Valencia, AO. The role of error-prone DNA polymerases and the activity of uracil DNA glycosylases on spontaneous mutagenesis in Caulobacter crescentus. [Masters thesis (Microbiology)]. São Paulo: Instituto de Ciências Biomédicas, Universidade de São Paulo; 2017

In this work we analyzed the role of DNA polymerases $\operatorname{din} B$ and dnaE2 in spontaneous mutagenesis in $C$. crescentus, using two molecular markers: $x y l-b l a$ and Cltet. Our studies show that there is no significant difference in mutation rates in both markers between $\operatorname{din} B, d n a E 2$ and wild type; this agrees with previous results using $r p o B$ gene. Here, we report that there is a predominance of $A T \rightarrow G C$ transitions in either $c /$ gene or $x y / R$, which was also shown in $r p o B$; however, this differs in $P x y / X$ region of $x y l-b l a$. We also observed that $x y / R$ presents a mutation hotspot that promotes cytosine insertion after base 230. The presence of small one-base deletions (frameshifts-1) in wild type but this type of mutation does not occur in the $\operatorname{din} B$ strain. These results suggest an important role for $\operatorname{din} B$ in the formation of deletions (frameshifts-1) in vivo in C. crescentus. We also saw that 4-NQO agent does not induce mutagenesis in C. crescentus, as it does in E. coli. Finally, the results demonstrate a poor efficiency in UDG activity in $C$. crescentus, when compared to E. coli.

Keywords: C. crescentus. spontaneous mutagenesis. DNA polymerases. 


\section{INTRODUÇÃO}

\subsection{Caulobacter crescentus}

Algumas espécies bacterianas possuem habilidades especificas para desenvolver características morfológicas programadas, que permitem a sua adequação às mudanças no ambiente natural. $O$ estudo desses sistemas em bactérias é importante para o entendimento de processos básicos presentes em muitos organismos (McAdams, Shapiro, 2009). A subdivisão das alfaproteobacterias inclui várias espécies de bactérias Gram negativas de vida livre de importância clínica e ambiental (Collier, 2016). Um representante deste seleto grupo bacteriano é a espécie Caulobacter crescentus. Esta bactéria se caracteriza por estar presente em meios aquáticos oligotróficos e em solos com a presença de poucos nutrientes (Laub et al., 2007). Ao contrário de alguns organismos procariotos, esse organismo replica seu cromossomo só uma vez durante seu ciclo de divisão celular.

Uma característica importante desse organismo é sua divisão celular assimétrica acoplada a eventos de diferenciação celular, que levam à formação de dois tipos de células em cada divisão (Brown et al., 2008). Cada uma das células geradas se diferenciam na sua morfologia, tamanho e função (Bodenmiller et al., 2004) (Figura 1A). A célula de tamanho menor é uma célula móvel que apresenta um flagelo em um dos polos, sendo incapaz de replicar seu cromossomo. Por outro lado, a célula de tamanho maior é uma célula séssil com a presença de um talo no polo oposto. Estes processos morfológicos são coordenados por um circuito genético e regulados no espaço e tempo (McAdams, Shapiro, 2011).

O sistema de controle do ciclo celular em Caulobacter crescentus envolve a participação de quatro proteínas regulatórias (CtrA, GcrA, DnaA e CcrM) que, juntas controlam a expressão de pelo menos 200 genes. Estas quatro proteínas são sintetizadas consecutivamente para modular funções que são executadas durante a divisão celular (Collier et al. 2006) (Figura 1B).

C. crescentus representa um modelo bacteriano potencial para análises ao nível genético e molecular de processos de diferenciação celular, uma vez que já possui seu genoma completamente sequenciado. Seu genoma está constituído 
num cromossomo circular de 4.016.942 pares de bases codificando um total de 3.767 proteínas. As regiões codificantes do genoma compreendem 90,6\% do total do genoma e aproximadamente um terço das proteínas são membros de 678 famílias de parálogos (Nierman et al. 2001). Por outro lado, C. crescentus contém 67\% de GC em seu genoma, sendo um dos objetivos deste trabalho, avaliar os mecanismos de mutagênese espontânea em um genoma com tal característica. Além disso, C. crescentus é um organismo de fácil manipulação genética.

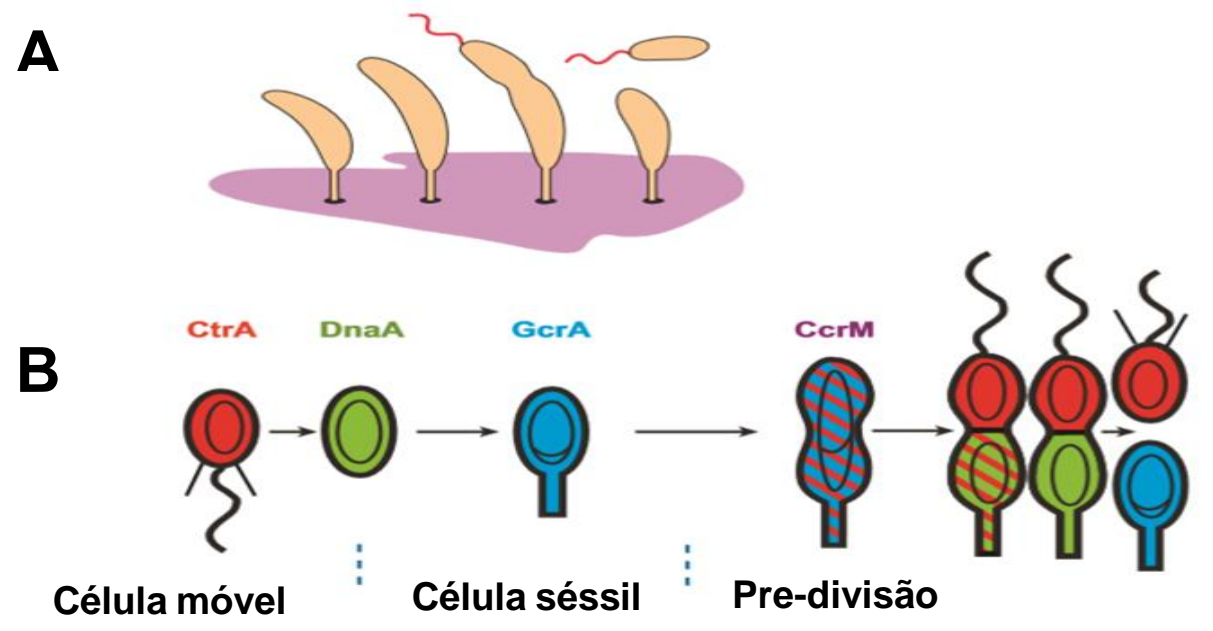

Figura 1 - Ciclo celular de $C$. crescentus. (A) morfologia da célula talo (séssil) e célula móvel. (B) Níveis de concentração das 4 proteínas regulatórias que controlam o ciclo celular (Laub et al. 2007)

\subsection{Mutações Espontâneas}

O DNA das células procarióticas, assim como as eucarióticas, sofre constantemente alterações químicas e estruturais na sua sequência. Estas mudanças podem ser fruto dos processos metabólicos celulares e ocorrer na ausência de fatores extracelulares (Dale et al., 2013).

Dentro da estrutura normal da molécula de DNA, se apresentam as complementariedades especificas de nucleotídeos, Adenina com a Timina e a Guanina com a Citosina. Foram descritos vários mecanismos que geram alterações da molécula do DNA. Como, por exemplo, trocas de bases por erros na replicação formados durante a síntese do DNA, que levam a mudanças na 
codificação genética. Arranjos genômicos causados pela inserção ou deleção de elementos móveis transponíveis, que também geram a perda da função das proteínas codificadas ou mudança de fase de leitura em regiões codificantes (Sargentini \& Smith 1985). Existem também sítios genômicos específicos (hotspots), onde mais frequentemente ocurrem erros na incorporação dos nucleotídeos durante o processo de replicação, causando o pareamento incorreto dos nucleotídeos (Friedberg 2003). Embora muitos desses processos que dão origem a alterações espontâneas sejam pouco compreendidos, eles desempenham um papel importante nos processos evolutivos e de seleção natural entre os organismos (Smith 1992).

\subsection{Fatores que contribuem para a mutagênese espontânea}

\subsubsection{Sítios propensos a alterações no DNA}

Alguns estudos mostraram que o DNA possui sítios genômicos específicos denominados hotspots e coldspots. Os hotspots usualmente são sequências curtas e repetidas de nucleotídeos, a maioria localizada em regiões homopoliméricas (sequencias repetidas de nucleotídeos), onde podem ocurrer a incorporação incorreta dos nucleotídeos durante o processo da síntese do DNA; desse modo, ocurrem em alto grau as mutações nessas regiões. Também existem outros sítios no DNA denominados coldspot, essas são regiões nas quais raramente pode dar-se uma alteração, mas sua natureza ainda não é bem compreendida (Das et al. 2012).

\subsubsection{Erros na síntese do DNA}

A maioria dos eventos espontâneos de mutação acontecem durante o processo de polimerização da molécula de DNA (Friedberg, 2006). Essa atividade replicativa é realizada em bactérias pelo complexo enzimático da DNA polimerase III, e auxiliado pela DNA polimerase I, além de outras proteínas associadas a este processo (Kelman e O'Donnell., 1995). A DNA polimerase III incorpora desoxiribonucleotídeos trifosfatados (dNTPs) em sequência, ligando ao carbono três do açúcar do nucleotídeo colocado previamente na fita 
crescente, usando como guia uma fita molde. Por conseguinte, a síntese do DNA ocorre na direção 5’ $\rightarrow 3^{\prime}$ (Livingston et al; 1975).

Em E. coli, assim como em outras bactérias a DNA polimerase III (holoenzima) contém dois cernes denominados pol III que são mantidos juntos como um dímero (T). Esse acoplamento na cadeia de DNA permite o retardamento da passagem da Pol III pela forquilha de replicação (McHenry 1982 e StudwellVaughan \& O’Donnell,1991).

O complexo enzimático Pol III esta composto de várias subunidades proteicas distintas e organizadas em três módulos funcionais (Onrust et al. 1995). A subunidade a representa o cerne catalítico da molécula, que realiza a função de polimerização e alongamento das fitas. Por outro lado, a subunidade $\beta$ consiste em um dímero que mantem o complexo enzimático da DNA polimerase ligado ao DNA em forma de grampo, isto também permite o deslocamento da enzima ao longo da cadeia e aumenta sua processividade. Por último, a subunidade $\varepsilon$ exerce uma atividade exonuclease $3^{\prime} \rightarrow 5^{\prime}$ (Glover \& McHenry 2001). A atividade exonuclease permite à enzima (Pol III) voltar e remover alguma base incorreta na sequência do DNA recém-sintetizado. A subunidade $\varepsilon$ é codificada pelo gene dnaQ. Estudos utilizando mutantes de E. coli, assim como em outros organismos deficientes nesse gene, mostraram que essas linhagens apresentam um forte fenótipo mutador (Kirby et al. 2006). Essa atividade de exonuclease, cuja função está associada ao complexo enzimático da DNA polimerase, desempenha um papel crítico e importante na afinidade e na correção de bases incorretamente incorporadas.

\subsubsection{Alterações químicas das bases nitrogenadas}

Três das quatro bases presentes normalmente no DNA (adenina, citosina e 5metil citosina, guanina), apresentam grupos aminos exocíclicos ligados a suas estruturas químicas (Friedberg 2003). Uma mudança, adição ou eliminação desses grupos modificam as propriedades destas bases, promovendo subsequentemente uma instabilidade na molécula de DNA. Essas alterações ocorrem de forma espontânea sob certas condições de pH e temperatura. Assim, como resultado das bases afetadas, temos uma conversão a diferentes produtos 
incomuns como: hipoxantina, uracila, timina e xantina respectivamente (Lindahl 1993).

\subsubsection{Desaminacão da citosina}

A desaminação da citosina é uma forma de transformação química da base citosina para uracila (Figura 2). Uracila encontra-se presente no RNA e ausente no DNA, no entanto, a uracila pode estar ocasionalmente presente no DNA pela desaminação da citosina. Observou-se, em células de mamíferos que, a desaminação ocorre entre 100 a 500 vezes por genoma por dia, de forma espontânea (Lindahl 1993). Também em cepas mutantes de E. coli com falha na remoção de uracila, notou-se um aumento na taxa de mutações espontâneas, causando transições de GC $\rightarrow$ AT (Frederico et al. 1990). Por outro lado, a desaminação da citosina acontece de 200 a 300 vezes mais rápido em uma fita simples de DNA do que na dupla fita.
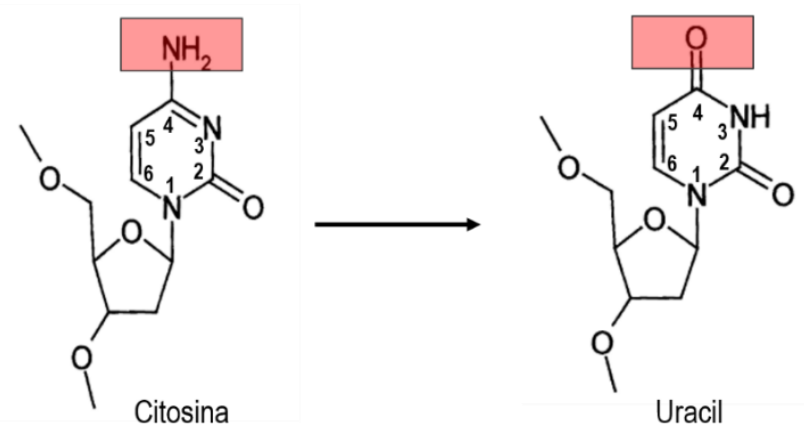

Figura 2 - Perda do grupo amino na posição 4 da citosina, formando uracila. Adaptado de (Friedberg, 2006).

Como se sabe, trechos de fita simples de DNA estão presentes em regiões como a forquilha de replicação e na abertura da dupla hélice da molécula do DNA na transcrição, sendo esses lugares mais propensos a uma desaminação constante (Friedberg, 2006).

Dois possíveis mecanismos para a desaminação da citosina foram já descritos. O primeiro compreende o ataque direito ao carbono 4 do anel da pirimidina por um grupo ceto $(\mathrm{C}=\mathrm{O})$, levando à perda do grupo amino (Figura 3 ); sendo essa 
reação catalisada por ácidos presentes no meio intracelular. Não obstante, as moléculas da água também podem exercer reações de protonação das bases, no caso catalisadas por alguns ácidos (Lindahl, 1993). Uma segunda via alternativa da desaminação hidrolítica constitui a reação de adição - eliminação, causada por bissulfitos com a formação de intermediários de 5,6 dihidro-citosina e 5,6 dihidro-uracila -6- sulfanato como se ilustra na Figura 3 (Friedberg, 2006). Outros fatores físicos como formação de dímeros de ciclo-butano induzido pela radiação UV, ou químicos pela presença de ácido nítrico na transformação química da citosina (Burger et al., 2003) também afetam a desaminação das citosinas. De outro lado, a presença de uracila no DNA também pode dar-se durante a síntese semiconservativa de DNA, estando presente nos iniciadores ligados na formação da fita descontinua (Olinski et al., 2010).

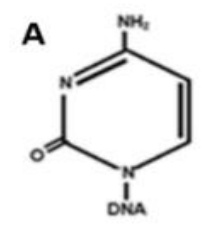

Citosina

$$
\text { 文 }
$$

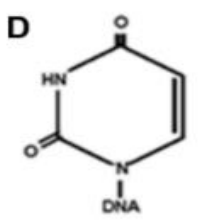

Uracil

\section{5,6 dihidro-citosina sulfanato}
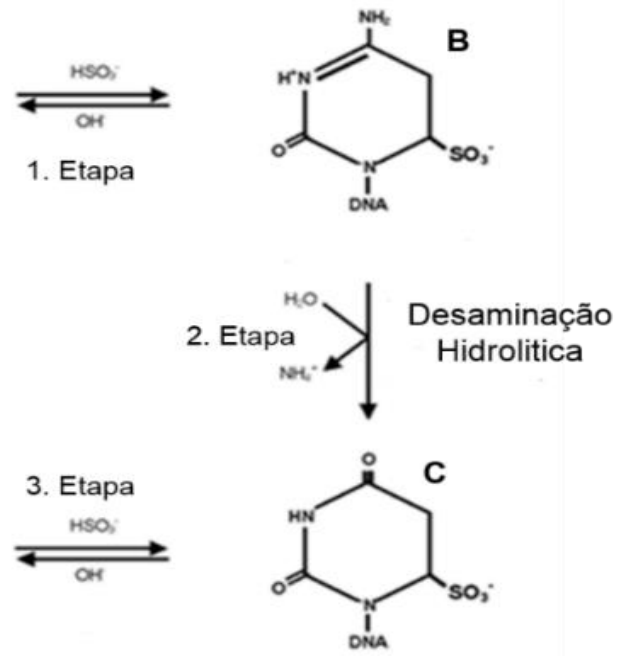

5,6 dihidro-uracil sulfanato

Figura 3 - Mecanismos de desaminação hidrolítica da citosina: (A) e (D) ataque direito ao carbono 4 da molécula. (A), (B), (C) e (D) transformação indireta da molécula. Adaptado de (Friedberg, 2006).

\subsubsection{Incorporação de uracila na replicação semiconservativa}

Outra forma principal causando a presença da uracila na sequência do DNA é por consequência da síntese da timina (Friedberg, 2006). A DNA polimerase replicativa pode incorporar incorretamente dUTP ao contrário de dTTP, e esse 
fato é devido a sua similaridade estrutural (Olinski et al., 2010). Também essa incorporação incorreta depende das concentrações de dUTP dentro da célula (Figura 4). Fisiologicamente, se estima que dUTP apresenta uma concentração muito baixa, de aproximadamente $0,2 \mu \mathrm{M}$, enquanto que a concentração de dTTP é de cerca de 30 a $37 \mu \mathrm{M}$ (Traut, 1994). Por outro lado, a enzima dUTPase mantem um controle sobre os níveis de dUTP dentro da célula, evitando assim a introdução da uracila no DNA (Friedberg, 2006).

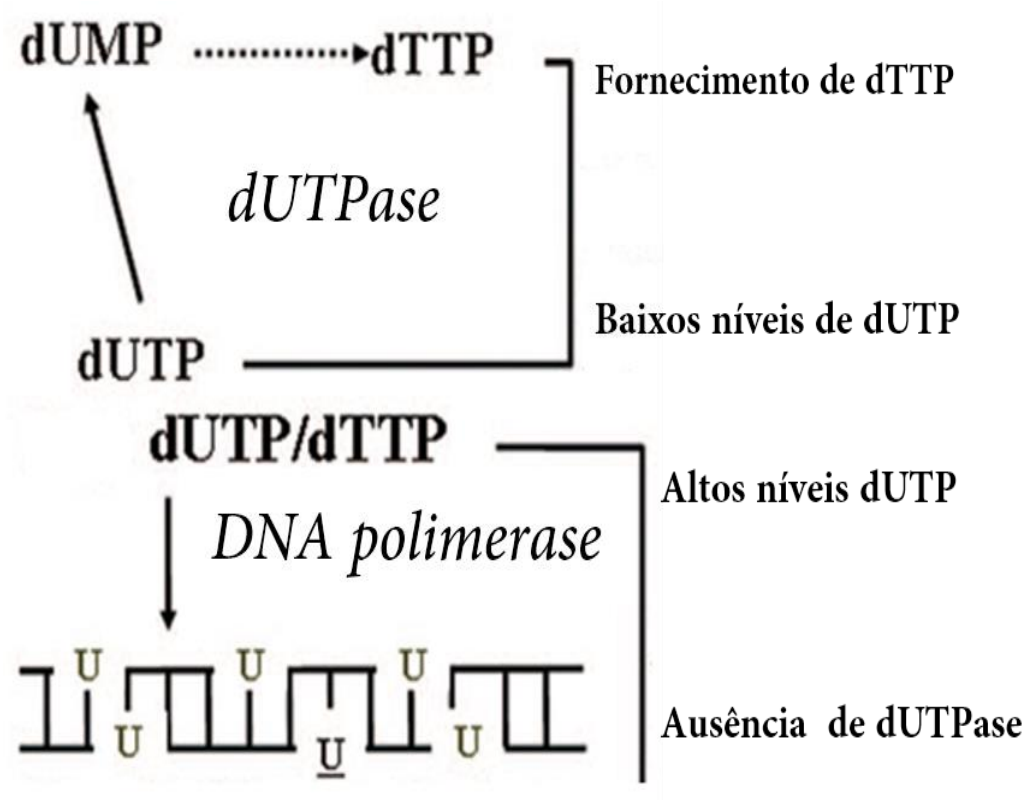

Figura 4 - Via de incorporação de uracila na replicação semiconservativa. Adaptado de Vértessy e Tóth, 2009.

\subsubsection{Mecanismo de reparo por excisão de bases (BER)}

Apresença da uracila no DNA é muito mutagênica, se ela não é detectada e retirada da molecula, podem ocorrer a transição de bases $\mathrm{GC} \rightarrow \mathrm{AT}$, após fixação da mutação no seguinte ciclo da replicação (Frederico et al., 1990). No entanto, existe um sistema de reparo para a excisão da uracila que envolve as enzimas uracila DNA glicosilases (UDGs) (Dianov, Lindahl, 1994). 
Em bactérias, assim como na maioria dos organismos, foram identificadas pelo menos seis diferentes estratégias que lidam com lesões do DNA. Essas estratégias incluem a síntese translesão, reversão direta, reparo por recombinação, reparo por excisão de nucleotídeos, reparo de bases mal emparelhadas e o reparo por excisão de bases (Friedberg, 2006). Muitos danos são reparados pelo mecanismo BER (reparo por excisão de bases). Esse sistema envolve as enzimas DNA glicosilases, conservadas em vários organismos, e divididas em duas classes, monofuncionais e bifuncionais, dependendo de seu mecanismo catalítico, conforme ilustrado na Figura 5 (Fromme et al., 2004).

As DNA glicosilases monofuncionais catalisam suas reações usando uma molécula de água em uma única etapa, removendo a base diretamente da desoxirribose.

As DNA glicosilases bifuncionais clivam a ligação $\mathrm{N}$-glicosídica, mas ao invés da água, utilizam um grupo amino da sua estrutura gerando uma base Schiff como intermediário, facilitando uma segunda atividade enzimática que é a clivagem da ligação fosfodiéster da estrutura no lado 3' da lesão ( $\beta$ - eliminação) do DNA. Algumas DNA glicosilases bifuncionais também podem clivar a ligação fosfodiéster no lado 5 ' fosfato da lesão ( $\delta$ - eliminação) do DNA (Drohat, Maiti, 2014).

Por outro lado, as enzimas com atividade de AP liase promovem a formação de sítios abertos de DNA denominados sitos abásicos, contendo resíduos de desoxinucleotídeos - 5 ' fosfato e aldeídos 3' $\alpha \beta$ - insaturados, que posteriormente são processados pelas enzimas fosfodiesterases (Friedberg, 2006). 


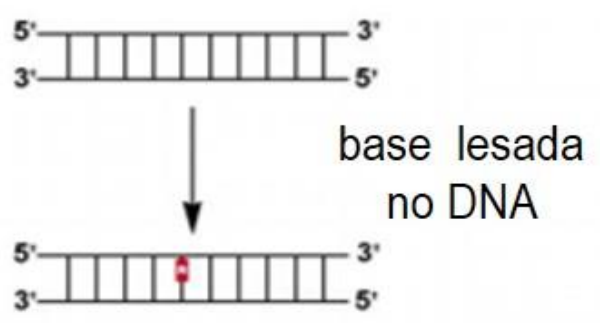

\section{DNA glicosilase Monofuncional}
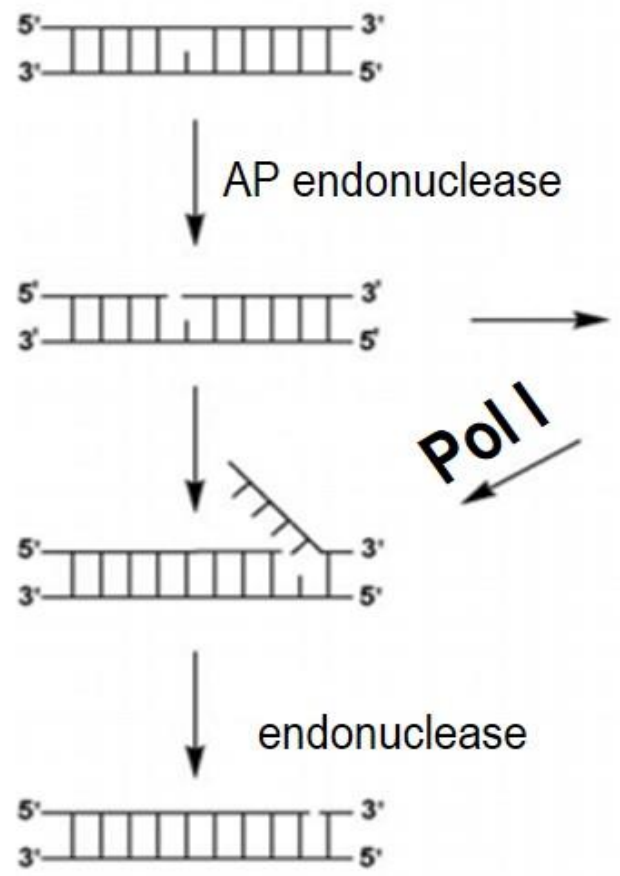
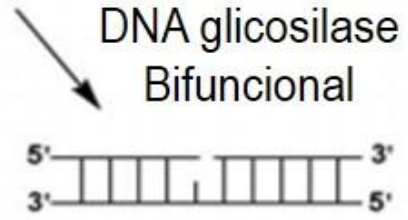

AP endonuclease

\section{Pol I}
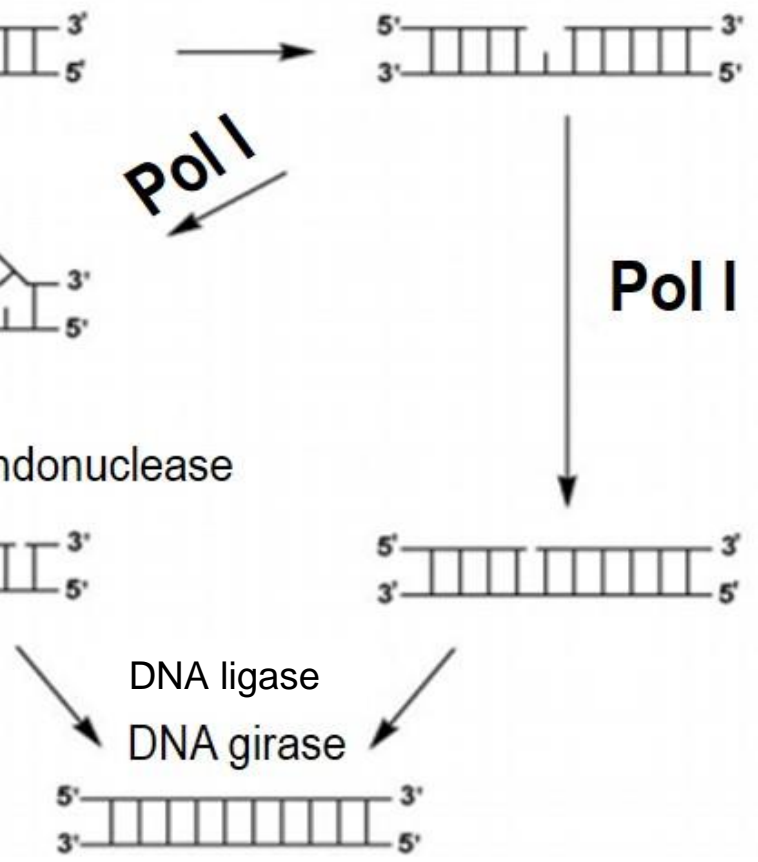

Figura 5 - Modelo proposto do mecanismo de reparo BER em bactérias. Duas possíveis vias podem atuar dependendo da espeficidade da enzima DNA glicosilase (monofuncional ou bifuncional). A DNA glicosilase monofuncional hidrolisa a ligação glicosídica removendo a base do esqueleto açúcar- fosfato originando um sitio AP. A DNA glicosilase bifuncional além de possuir atividade glicosídica possui uma atividade AP liase, essa atividade permite clivar a ligação fosfodiester do sitio AP. As enzimas AP endonuclease promovem a remoção dos sítios AP e finalmente a DNA polimerase I incorpora um novo nucleotídeo e a DNA ligase sela a ligação deste com o DNA. Adaptado de (Kurthkoti, Varshney, 2011)

\subsubsection{As uracila DNA glicosilases}

Dentro do grupo das DNA glicosilases monofuncionais existem as denominadas uracila DNA glicosilases (UDGs), que atuam no início do reparo, removendo a uracila presente no DNA, clivando especificamente a ligação dessa base com o 
esqueleto açúcar- fosfato, formando um sitio abásico (AP). Logo depois, esse espaço abásico é retirado pela ação da enzima AP- endonuclease permitindo a DNA polimerase I (Pol I) corrigir a lacuna na sequência nucleotídica, recolocando a base original (Caldecott, 2003).

A superfamília da uracila DNA glicosilases (UDG) está dividida em cinco famílias, e mais uma sexta família de UDGs putativa não caraterizada funcionalmente. A primeira família descrita de UDGs é representada pelo gene ung em E. coli e presente também em outros organismos tais como leveduras, células de mamíferos e células de plantas, no entanto, ausente nas arqueas e insetos (Schormann et al. 2014). Esse grupo de UDGs removem a uracila tanto da fita simples quanto como de dupla fita do DNA. As enzimas da segunda família são as uracila DNA glicosilases MUG, elas exibem uma atividade de excisão em três emparelhamentos inadequados específicos com a uracila, T:U, G:U e C:U (Lee et al. 2015). De igual forma, a Timina DNA glicosilase (TDG) pertence também à segunda família, mas só está presente em células eucariotas, sendo sua função retirar o 3-N $\mathrm{N}^{4}$ etenocitosina e uracila (Lutsenko \& Bhagwat 1999). A terceira família apresenta uma atividade específica para DNA em fita simples, presente em vertebrados e insetos (Boorstein et al. 2001).

As enzimas da quarta família das UDGs são as termoestáveis, e se encontram no grupo das arqueas termofílicas e em algumas bactérias. Sua atividade é baseada na remoção da uracila da fita simples, assim como na fita dupla do DNA. No entanto, enzimas da família cinco das UDGs agem só na fita dupla, sendo caracterizadas principalmente em arqueas hipertermofílicas (Sartori et al. 2002). Foram identificados quatro genes que codificam as uracila DNA glicosilases em Caulobacter crescentus; CCNA_02418, CCNA_01394, CCNA_01618 e CCNA_02166 (Martins-Pinheiro et al. 2007). Os dois primeiros genes codificam uracila DNA glicosilases classificadas na família 4 (CCNA_02418 e CCNA_01394). O gene CCNA_01618 pertence à família 5 (Marks et al. 2010). No entanto, o gene CCNA_02166 pertence a uma família ainda não caraterizada funcionalmente. $E ́$ interessante notar que, os genes CCNA_01394 e CCNA_01618 são essenciais para a viabilidade celular em C. crescentus (Christen et al. 2011). 
Estudos moleculares mostraram que existem fortes inibidores das uracila DNA glicosilases. Os bacteriófagos PBS 1 e PBS2 que infectam a bactéria Bacillus subtilis normalmente possuem mais uracila do que timina dentro de seu genoma. Assim, para evitar o comprometimento da estrutura do DNA por causa da atividade das UDGs do seu hospedeiro, expressam um determinado gene denominado ugi. O produto do gene ugi interage com o sítio ativo da molécula das UDGs, desse modo, esta interação forma um complexo estequiométrico das proteínas UDG - UGI. Esse complexo químico UDG - UGl é formado em dois estágios que acoplam as duas estruturas interagindo e bloqueando o sítio ativo das UDGs. Como resultado, se estabelece um estado irreversível da molécula, assim, sua função é inibida (Zhigang et al. 1991). O complexo UDG - UGl é observado na Figura 6.

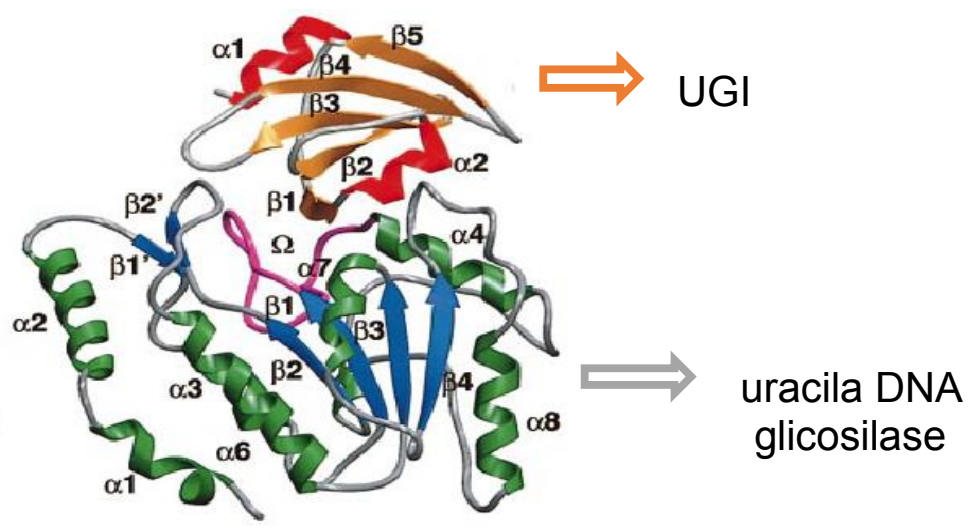

Figura 6 - Complexo UDG - UGI em E. coli. Na parte superior encontra-se o produto do gene Ugi, interagindo com o sitio ativo da enzima uracila DNA glicosilase (UDG) mostrado com o símbolo ômega $(\Omega)$ na parte inferior. Código do PDB 1LQG (Putnam et al. 1999).

\subsubsection{DNA Polimerases de síntese translesão (TLS)}

A holoenzima DNA polimerase (Pol III) participa ativamente na incorporação de nucleotídeos no DNA, conseguindo realizar esse processo com uma alta eficiência e alta fidelidade, podendo alcançar uma incorporação de 1000 dNTPs por segundo, com uma taxa muito baixa de erro (1 erro por $10^{6}$ incorporações) (Sloane et al. 1988). Por outro lado, o DNA está constantemente exposto a variados agentes químicos e físicos que podem causar alterações tais como; dímeros de pirimidina, $\mathrm{OH}^{8}$-Gua, $\mathrm{O}^{6}$-metil-guanina ou $\mathrm{O}^{4}$-metil-timina (David et al. 2007; Warren et al. 2006). Alguns desses tipos de alterações impedem a 
incorporação de nucleotídeos complementares à fita molde, ocasionando um bloqueio da replicação (Friedberg, 2006). Para tentar superar a parada do processo replicativo, as células possuem um determinado número de enzimas especializadas denominadas DNA polimerases de síntese translesão (Figura 7). Essas são capazes de colocar nucleotídeos usando como molde uma fita de DNA lesada com uma baixa fidelidade, ou seja, propensas a erro, desse modo, podendo efetivamente restabelecer a continuidade da síntese do DNA (Andersson et al. 2010).

As DNA polimerases de síntese translesão estão classificadas dentro da família $\mathrm{Y}$, com base em duas características bioquímicas. A primeira é a baixa fidelidade pelo fato de não possuírem atividade exonuclease 3'- 5', aumentando consideravelmente a incorporação de bases incorretas sem existir a propriedade revisora, levando a altas taxas na mutagênese no genoma (Kokoska et al., 2002). A segunda se refere a sua estrutura molecular baseada em quatro domínios principais, um domínio catalítico ( $\mathrm{palm}$ ) que representa o sitio ativo da molécula, possuindo um espaço de acomodação de vários nucleotídeos, os domínios denominados Finger e Thumb, estes são curtos e grossos, tendo uma interação fraca, tanto com o DNA, quanto com o nucleotídeo a ser colocado, razão pela qual sua pouca fidelidade, e o domínio Little Finger, que é um mediador da interação entre a enzima e o sitio lesado do DNA (Prakash et al. 2005).

Esses domínios são conservados em todas as enzimas da família Y (Goodman 2002). Assim, as DNA polimerases da família $Y$, possuem a habilidade de incorporar nucleotídeos usando como molde o DNA com alterações químicas na sua estrutura (Waters et al. 2009). Contudo, as DNA polimerases da família Y, atuam eficientemente na incorporação de nucleotídeos usando como molde regiões lesadas do DNA, mas sua atividade aumenta as taxas de mutagênese espontânea no genoma (Friedberg, 2006; Sale et al., 2012). 

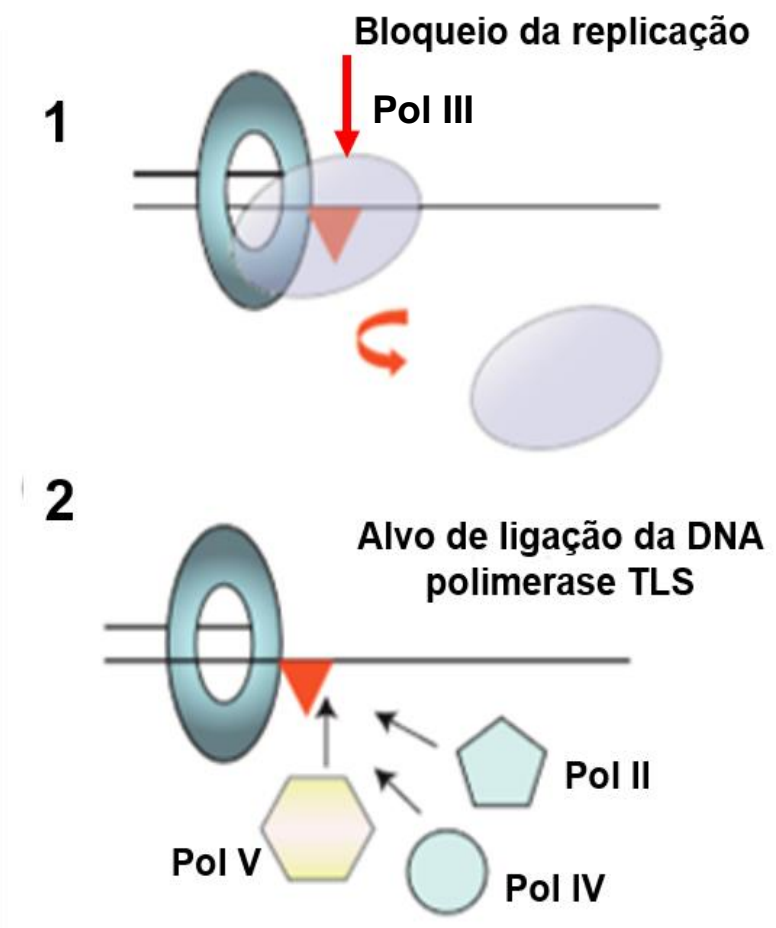

3

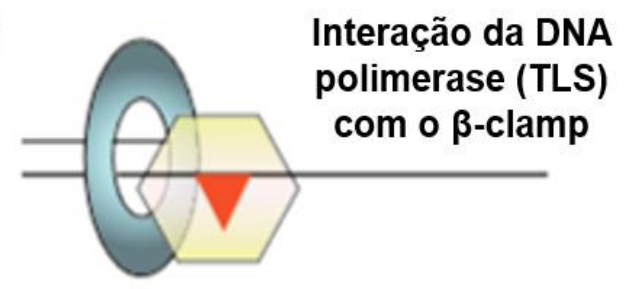

Síntese translesão
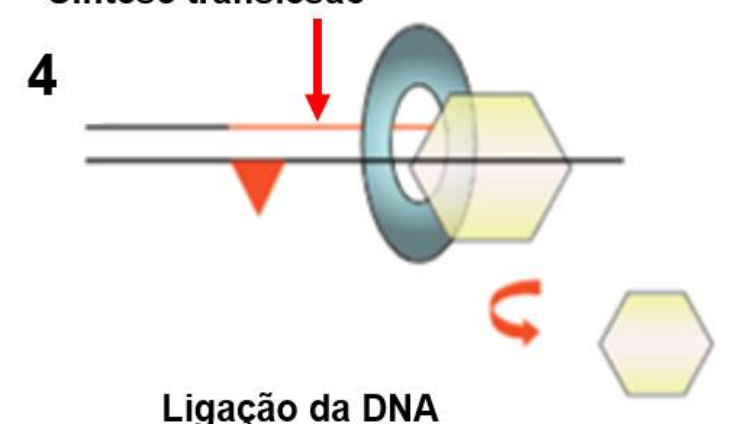

5 polimerase III ao DNA

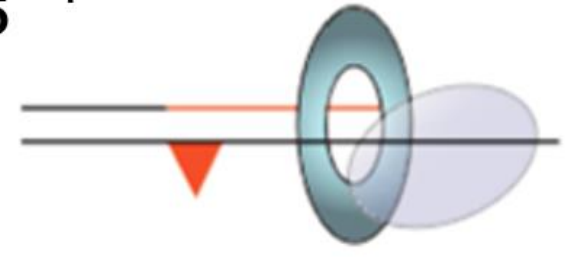

6

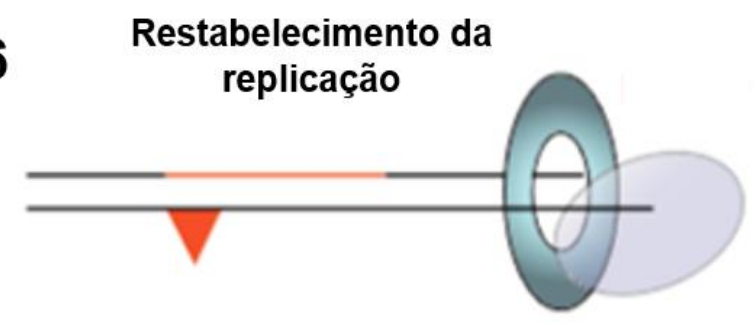

Figura 7- Modelo de síntese translesão em E. coli. (1) bloqueio da replicação e dissociação da DNA polimerase replicativa (Pol III). (2) DNA lesado sinal para o recrutamento de alguma DNA polimerase TLS, Pol II, Pol IV ou Pol V. (3) interação da DNA polimerase (TLS) com o grampo ( $\beta$ - Clamp) permitindo a ancoragem ao DNA. (4) Incorporação de nucleotídeos em frente à lesão sem atividade exonuclease (propensa a erro). (5) montagem novamente do complexo da Holoenzima Pol III. (6) Restabelecimento da replicação. Adaptado de (Fuchs, Fujii, 2013).

\subsubsection{DNA polimerase IV (DinB)}

No modelo bacteriano de Escherichia coli, foram descritas duas DNA polimerases da família Y, a Pol IV e Pol V. A Pol IV é codificada pelo gene dinB sendo a expressão desse gene induzida pela resposta SOS (Jarosz et al. 2007). O sistema SOS consiste num mecanismo de resposta e tolerância a danos no DNA. Desse modo, quando o processo de replicação do DNA é bloqueado por causa de uma lesão, é o sinal para ativação do sistema SOS. O primeiro passo é a polimerização de RecA na região de fita simples produzida pela forquilha de replicação, formando um filamento nucleoprotéico (ligação $\operatorname{Rec} A^{*}$ e fita simples DNA). Logo após a formação desse filamento, se produz uma atividade auto 
proteolítica do repressor LexA, que mantem uma repressão constante nas regiões promotoras de aproximadamente 40 genes, entre eles os genes $\operatorname{din} B$ e umuDC (Friedberg, 2006), produzindo uma resposta global ao dano no DNA.

O gene $\operatorname{din} B$ foi identificado pela primeira vez como um gene induzido pelo dano no DNA em E. coli (Kenyon \& Walker 1980). DinB representa a única DNA polimerase TLS conservada nos três reinos da vida (bactérias, eucariotas e archea) (Ohmori et al. 2001), e sua presença no meio intracelular equivale a uma concentração de 250 moléculas/célula, sendo essa concentração maior quando comparada com a Pol III em E. coli (Kim et al., 2001). Ensaios in vitro com DNA polimerase DinB mostraram o seu envolvimento na síntese translesão com uma alta eficiência, mas com pouca fidelidade no pareamento dos nucleotídeos (Walsh et al. 2011).

Em E. coli, o gene $\operatorname{din} B$ foi identificado como um primeiro de quatro genes presentes em um operon e induzidos como resposta ao dano no DNA (Mckenzie et al. 2003). Estudos realizados neste organismo e em cepas deficientes do gene $\operatorname{dinB}$ mostraram que a perda da função do gene não afeta as taxas de mutação espontânea quando comparado com a linhagem selvagem.

Em $P$. aeruginosa foram observados resultados semelhantes, mostrando que mutantes $\operatorname{din} B$ apresentam uma frequência de mutação igual a cepa selvagem, revelando que a DNA polimerase DinB não influência a mutagênese espontânea em E. coli e em $P$. aeruginosa durante o crescimento exponencial (Mckenzie et al. 2003; Sanders et al. 2011).

A DNA polimerase DinB também tem uma participação ativa na prevenção de mutagênese induzida pela presença de agentes genotóxicos como o 4-NQO (4Nitroquinolona - 1 óxido). Este agente químico promove lesões no DNA pela formação de adutos na posição $N^{2}$-guanina, que levam a um bloqueio da replicação (Panigrahi \& Walker 1990). Estudos in vitro e in vivo em mutantes $\operatorname{din} B$ de $E$. coli evidenciaram uma maior sensibilidade às lesões causadas pelo agente 4-NQO e maior a formação de frameshifts -1, quando comparado com a cepa selvagem (Jarosz et al. 2006). Isto mostra um papel importante de DinB na prevenção desse tipo mutação em E. coli. No entanto, existem outros agentes químicos que não causam lesão no DNA ( $\beta$ - lactâmicos), mas também podem 
induzir a expressão do gene dinB (Pérez-Capilla et al. 2005). Ademais, é sabido que a superexpressão de $\operatorname{din} B$ causa aumento nas taxas de mutação e é a base da mutagênese gratuita (ou seja, sem danos no DNA) que ocorre quando as células de E. coli experimentam indução da resposta SOS (Kim et al. 1997).

Além disso, dinB está envolvido no fenômeno de mutagênese na fase estacionaria (Galhardo et al. 2009) e na mutagênese induzida por antibióticos (Gutierrez et al. 2013). Desta forma, $\operatorname{dinB}$ apresenta um papel dúbio na mutagênese em $E$. coli, ora prevenindo mutações, ora promovendo seu aparecimento. O seu papel em outros microrganismos ainda é pouco estudado.

O gene dinB apresenta um homologo em C. crescentus (Figura 8), mas, este gene não é regulado pelo mecanismo SOS (Galhardo et al., 2005). Avaliando o papel de DinB em $C$. crescentus nosso laboratório observou que o gene dinB não é induzido por agentes genotóxicos como: mitomicina $C$, peroxido de oxigênio, metanossulfanato de metila (MMS), exposição a luz UV ou entrada na fase estacionária (Galhardo et al., 2005 e dados não publicados), mostrando um papel diferente do já observado em E. coli para esse gene ( Janion, 2008; Layton, Forter, 2003; Lewis et al., 1994; Oh et al., 1999,).

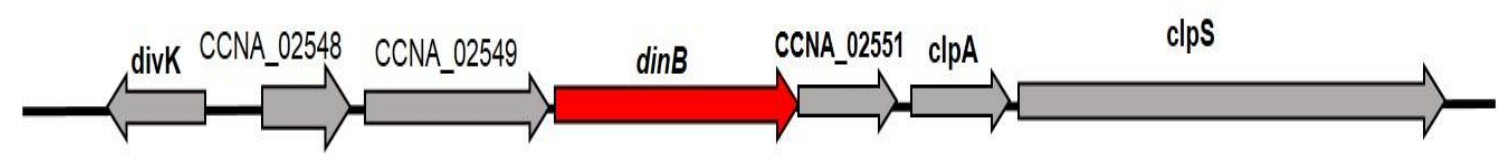

Figura 8 - Contexto gênico do gene $\operatorname{din} B$ em C. crescentus.

\subsubsection{DNA polimerase $\mathrm{V}\left(\mathrm{UmuD}_{2} \mathrm{C}\right)$}

Em 1974, Radman foi o primeiro a propor um modelo para o sistema SOS em $E$. coli. Embora seja parte de uma resposta induzida por dano no DNA, ainda não era elucidada a correlação entre a resposta SOS e mutagênese na aquela época. A identificação de umuC por Kato e Shinoura em 1977 e uvm por Steinborn em 1978, levou à constatação que a mutagênese induzida por danos em E. coli não é um processo passivo. 
Os primeiros modelos de mutagênese propunham que as proteínas UmuD e UmuC eram fatores acessórios da DNA Pol III, os quais permitiriam realizar um bypass ante uma lesão no DNA, restaurando o processo de replicação. Hoje em dia, sabe-se que as proteínas Umu codificam uma DNA polimerase de baixa fidelidade (Pol V) que pode catalisar a síntese translesão no DNA (TLS) atuando em vários tipos de lesões no genoma de E. coli (Goodman et al. 2016).

A PolV é formada pelos produtos do operon $u m u D C$, regulado pela resposta SOS. Os níveis de UmuD e UmuC na célula são regulados por proteólise através da proteína Lon protease dependente de ATP. A proteína UmuC é expressa 30 minutos após o dano ao DNA, e sequestrada sob a membrana celular interna (pela interação hidrofóbica), a interação de UmuC e UmuD'2 (homodímero de UmuD clivado) permite a liberação de UmuC da membrana interna, formando o complexo UmuC-UmuD'2 (PolV) (Goodman et al. 2016). Atualmente é conhecido que muitas bactérias gram negativas carregam ortólogos de Pol V.

Em E. coli foi reportado que elevados níveis de expressão dos produtos dos genes umuDC leva a um fenótipo sensível ao frio, e por sua vez esta característica está correlacionada a rápida inibição da síntese do DNA (Opperman et al. 1996).

Também os produtos dos genes umuDC parecem ter um papel fisiológico na rápida transição da fase exponencial para a fase estacionária do crescimento bacteriano, e correlacionado com o aumento da sobrevivência celular após exposição de luz UV na fase estacionária em E. coli (Murli et al. 2000). Em outras bactérias, incluindo $C$. crescentus, homólogos de umuDC estão ausentes. No entanto, muitas dessas possuem o operon imuAB dnaE2, que têm uma função semelhante a umuDC na resposta SOS (Galhardo et al. 2005).

\subsubsection{As proteínas ImuAB DnaE2}

Caulobacter crescentus apresenta um operon com três genes: imuA, imuB e dnaE2 (imuC) (Figura 9) envolvidos na resposta SOS e responsáveis pela mutagênese induzida por danos ao DNA (Galhardo et al. 2005). Esses genes estão frequentemente presentes em diferentes classes de bactérias com alto 
conteúdo de GC, e alguns autores propõem que a presença de imuC tem uma influência no viés mutacional, favorecendo esse alto conteúdo de GC (Zhao et al., 2007). Analisando-se as mutações que levam à resistência à rifampicina (no gene rpoB) em $C$. crescentus, foi observado que as taxas de mutações espontâneas de mutantes dnaE2 são iguais ao do tipo selvagem, sugerindo que este gene não contribui para a mutagênese espontânea neste organismo (Martins-Pinheiro et al., 2016, submetido). imuC co-ocorre com imuA e imuB (homólogo de DNA polimerases da família Y) em genomas bacterianos. Apesar de possuir similaridade com proteínas da família $Y$ de polimerases, ImuB parece não ter resíduos catalíticos necessários para realizar atividade de polimerase (Warner et al., 2010). O cassete imuABC representa uma estratégia alternativa para a síntese translesão em alguns grupos de bactérias (Ippoliti et al., 2012).

As DNA polimerases da família $Y$ e ImuC contribuem para a restauração da replicação após o dano no DNA. Alguns organismos, como E. coli, possuem duas a três moléculas de DnaE dentro do complexo enzimático Pol III, codificadas por um único gene dnaE. Em outros organismos, como $B$. subtilis, a subunidade a é codificada por dnaE e outra por polC, cada uma delas apresenta papéis distintos, correspondentes a síntese do DNA sobre a fita líder e a fita tardia respectivamente, durante o processo da replicação. No entanto, em $B$. subtilis DnaE é induzido pelo mecanismo da resposta SOS e realiza síntese translesão, similarmente, a DnaE de S. pyogenes pode também realizar a TLS (Ippoliti et al., 2012).

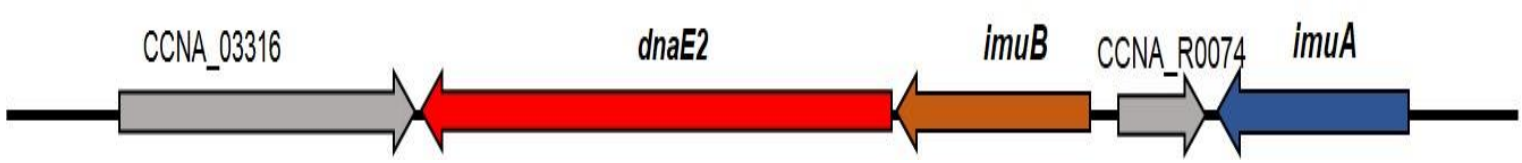

Figura 9 - Contexto gênico do operon imuAB no mapa genético de $C$. crescentus.

Em Mycobacterium tuberculosis, os genes imuA-imuB-dnaE2 são essenciais para induzir mutagênese e tolerância ao dano ao DNA. Através de ensaios de duplo híbrido, mostrou-se que ImuB interage com ImuA' e DnaE2, assim como 
com o "beta-clamp". A interrupção dessa interação entre ImuB-beta clamp reduz significativamente a mutagênese e tolerância ao dano. Apesar de ImuB fazer parte da família $Y$, não apresenta os aminoácidos conservados do sitio ativo requeridos para atividade de polimerase. Acredita-se que a única atividade de polimerase é conferida por DnaE2. Estes dados sugerem uma interação das proteínas ImuB e DnaE2, onde ImuB recruta o complexo para os sítios de replicação através da sua interação com a cinta beta, e DnaE2 atua como polimerase TLS (Warner et al., 2010).

\subsection{Alto conteúdo de GC em C. crescentus}

Outro ponto importante a ser considerado na análise das mutações espontâneas é a proporção de GC (guanina - citosina) no genoma das bactérias e outros organismos. Existe uma alta variedade no conteúdo de GC entre os grupos bacterianos, variando de $16,5 \%$ a $75 \%$ (Nakabachi et al., 2006). Por exemplo, Escherichia coli possui aproximadamente $50 \%$ de GC, enquanto que outras bactérias como Pseudomonas aeruginosa e Mycobacterium smegmatis, possuem valores elevados de GC, acima de 65\% (Jacobs Jr. et al., 1989).

É interessante notar que esta variação no conteúdo de GC pode ser causada por dois fatores não mutuamente exclusivos: 1) a seleção para os diferentes conteúdos, favorecendo A:T em alguns organismos e G:C em outros. 2) diferenças no viés de mutação. É sabido que em $E$. coli e em eucariotos como $S$. cerevisiae e humanos, as transições $\mathrm{GC} \rightarrow$ AT são as mutações mais comuns (Friedberg, 2006). Usando a análise comparativa de genomas, foi proposto que a mutagênese $\mathrm{GC} \rightarrow \mathrm{AT}$ é a universalmente predominante em bactérias, mesmo em organismos ricos em GC ( Hershberg, Petrov, 2010; Hildebrand et al., 2010). Desta forma, a seleção natural seria a única responsável por manter os diferentes conteúdos de GC. Entretanto, não há demonstração experimental de tal fenômeno na literatura, que carece de estudos de mutagênese em organismos ricos em GC.

Nosso grupo vem estudando os processos de mutagênese na bactéria Caulobacter crescentus, cujo genoma possui um alto nível de GC (65\%). 
Linhagens com fenótipo mutador foram isoladas, a partir de uma varredura de uma biblioteca de mutantes com inserções aleatórias do transposon Tn5. Neste trabalho, o gene rpoB foi utilizado como marcador de mutagênese, buscando-se linhagens da biblioteca com maior frequência de mutantes resistentes a rifampicina. Vários genes já conhecidos foram identificados nesta varredura, tais como os genes mutL e mutS envolvidos no reparo de bases mal emparelhadas (mismatch repair, MMR) (Martins-Pinheiro et al.,submetido).

Apreciando os espectros de mutação em rpoB, foi observada uma predominância mutacional de $A T \rightarrow G C$ tanto na linhagem selvagem NA1000 como nas linhagens mutantes (mismatch repair, MMR-) (Martins-Pinheiro et al. 2016 Submetido). Estes dados experimentais estão em desacordo com a proposta descrita anteriormente de universalidade de mutagênese $\mathrm{GC} \rightarrow \mathrm{AT}$ em bactérias e organismos com genomas ricos em GC ( Hershberg, Petrov, 2010; Hildebrand et al., 2010).

Do mesmo modo, nosso grupo avaliou a mutagênese em mutantes deficientes dos genes dinB e dnaE2 e utilizando o mesmo marcador rpoB. Os resultados mostram que tanto dinB como dnaE2 apresentam o mesmo predomínio de assinatura mutacional $A T \rightarrow G C$, já observado na linhagem selvagem (NA1000) e mutantes $\mathrm{MMR}^{-}$(dados não publicados). Além disso, notou-se, que as linhagens dinB e dnaE2 não apresentam diferenças significativas na frequência de mutação quando comparadas com a linhagem parental. Esses resultados sugerem que eventualmente os genes $\operatorname{dinB}$ e dnaE2 não influenciam a mutagênese espontânea em $C$. crescentus. Esses resultados diferem de hipóteses propostas por outros autores, que sugerem que a presença dos genes imuABdnaE2 favorecem o alto conteúdo de GC nas bactérias que os possuem (Zhao et al., 2007). Entretanto, os estudos prévios com o marcador rpoB não corroboram isso.

É necessário notar que o marcador rpoB detecta apenas mutações de troca de bases, e mesmo neste tipo de mutação, possui limitações quanto aos eventos que podem ser detectados fenotipicamente como Rif ${ }^{R}$ (Garibyan et al., 2003). Por isso, foi importante neste estudo considerar a caracterização da mutagênese espontânea em C. crescentus usando marcadores moleculares alternativos que detectem mutações do tipo frameshifts, transversões, transições, entre outras, 
evitando assim, introduzir o viés mutacional por causa da avaliação de um só marcador no genoma de $C$. crescentus. Esses marcadores moleculates alternativos são construções genéticas do tipo Forward, ou seja, que permitem detatar mutações por perda da função de genes e inseridas em diferentes regiões do genoma de $C$. crescentus. 


\section{CONCLUSÕES}

- Neste trabalho concluímos primeiro que as taxas de mutação medidas com o marcador xyl-bla não variam significativamente entre as cepas dinB, dnaE2 e parental. Estes dados coincidem também com os resultados prévios de nosso grupo usando o gene rpo $B$ como marcador, onde as DNA polimerases codificadas por $\operatorname{din} B$ e dnaE2 não promovem diferenças significativas nas taxas de mutação quando comparadas com a cepa parental.

- Em relação às trocas de bases, tanto no gene $c /$ como em $x y / R$, há um predomínio de mutações $A: T \rightarrow C: G$, como observado anteriormente em $r p o B$. Entretanto, nota-se que esta tendência é invertida em $P x y \mid X$. O gene xyIR apresenta um hotspot de mutação, com inserção de uma citosina após a base 230 .

- No gene $x y / R$, nota-se a presença de pequenas deleções (frameshifts -1) de uma base no genoma na cepa selvagem e $d n a E 2$, e tais deleções correspondem a aproximadamente a um terço das mutações observadas nessas cepas desconsiderando-se o hotspot. No entanto, esses tipos de mutação não estão presentes na linhagem $\operatorname{din} B$. Esses resultados sugerem um papel importante de $\operatorname{din} B$ na formação de deleções (frameshifts -1) in vivo em C. crescentus.

- Avaliando o papel de dinB e dnaE2 portando o marcador cltet, vimos que não existem diferenças quantitativas entre $\operatorname{din} B$ e $d n a E 2$, em comparação com a cepa parental, coincidindo com os dados obtidos no marcador xylbla e anteriormente observados no gene rpoB. Assim, as DNA polimerases DinB e DnaE2 não influenciam quantitativamente a mutagênese espontânea em C. crescentus. 
- Foi observado nos espectros de mutação do marcador cltet um grande número de inserções de uma base na cepa parental, bem como nas cepas dinB e dnaE2. Um dado interessante neste marcador foi a prevalência das deleções de uma base na cepa selvagem e dnaE2, mas não observado na cepa $\operatorname{din} B$, novamente demonstrando um papel importante da DNA polimerase DinB na formação desta classe de mutações.

- Os ensaios de incisão in vitro revelaram que a UDG presente em E. colie codificada pelo gene ung, apresenta uma maior atividade na incisão da uracila no DNA quando comparadas com as UDGs de C. crescentus. Também a presença do gene ugi não mostrou influenciar a mutagênese espontânea em C. crescentus.

- A alta variação experimental não permitiu inferir com precisão o papel de $\operatorname{dinB}$ e dnaE2 na mutagênese induzida por 4-NQO. Entretanto, fica evidente que este agente é pouco mutagênico para $C$. crescentus, ao contrário de E. coli. 


\section{REFERÊNCIAS*}

Andersson, D.I., Koskiniemi, S. \& Hughes, D., 2010. Biological roles of translesion synthesis DNA polymerases in eubacteria. Molecular microbiology, 77(3), pp.5408. Available at: http://www.ncbi.nlm.nih.gov/pubmed/20609084.

Ballal, R. et al., 2009. Fluorescent oligonucleotides can serve as suitable alternatives to radiolabeled oligonucleotides. Journal of Biomolecular Techniques, 20(4), pp.190-194.

Bennett, S.E. \& Mosbaugh, D.W., 1992. Characterization of the Escherichia coli uracil-DNA glycosylase??inhibitor protein complex. Journal of Biological Chemistry, 267(31), pp.22512-22521.

Benson, R.W. et al., 2011. An active site aromatic triad in escherichia coli DNA pol IV coordinates cell survival and mutagenesis in different DNA damaging agents. PLOS ONE, 6(5).

Bjedov, I. et al., 2007. Involvement of Escherichia coli DNA polymerase IV in tolerance of cytotoxic alkylating DNA lesions in vivo. Genetics, 176(3), pp.14311440.

Bodenmiller, D., Toh, E. \& Brun, Y. V., 2004. Development of Surface Adhesion in Caulobacter crescentus. Journal of Bacteriology, 186(5), pp.1438-1447.

Boorstein, R.J. et al., 2001. Definitive Identification of Mammalian 5Hydroxymethyluracil DNA N-Glycosylase Activity as SMUG1. Journal of Biological Chemistry, 276(45), pp.41991-41997.

Brown, P.J.B. et al., 2008. Complex Regulatory Pathways Coordinate Cell-Cycle Progression and Development in Caulobacter crescentus. Advances in Microbial Physiology, 54, pp.1-101.

Burger, A. et al., 2003. In vivo deamination of cytosine-containing cyclobutane pyrimidine dimers in E. coli: A feasible part of UV-mutagenesis. Mutation Research - Fundamental and Molecular Mechanisms of Mutagenesis, 522(1-2), pp.145-156.

Caldecott, K.W., 2003. Protein-protein interactions during mammalian DNA single-strand break repair. Biochemical Society transactions, 31(Pt 1), pp.247251.

Christen, B. et al., 2011. The essential genome of a bacterium. Molecular systems biology, 7, p.528.

Cirz, R.T. et al., 2005. Inhibition of mutation and combating the evolution of antibiotic resistance. PLoS Biology, 3(6), pp.1024-1033.

Collier, J., 2016. Cell cycle control in Alphaproteobacteria. Current Opinion in Microbiology, 30, pp.107-113.

\footnotetext{
* De acordo com:

International Committee of Medical Journal Editors. [Internet]. Uniform requirements for manuscripts submitted to biomedical journals. [2011 Jul 15]. Available from: http://www.nlm.nih.gov/bsd/uniform_requirements.htlm
} 
Collier, J., Murray, S.R. \& Shapiro, L., 2006. DnaA couples DNA replication and the expression of two cell cycle master regulators. The EMBO journal, 25(2), pp.346-356.

Das, S. et al., 2012. Identification of hot and cold spots in genome of Mycobacterium tuberculosis using Shewhart Control Charts. Scientific reports, 2, p.297. Available at: http://www.pubmedcentral.nih.gov/articlerender.fcgi?artid=3291883\&tool=pmce ntrez\&rendertype $=$ abstract.

David, S.S., O'Shea, V.L. \& Kundu, S., 2007. Base-excision repair of oxidative DNA damage. Nature, 447(7147), pp.941-950. Available at: http://www.ncbi.nlm.nih.gov/pubmed/17581577\nhttp://www.nature.com/nature/j ournal/v447/n7147/pdf/nature05978.pdf.

Dianov, G. \& Lindahl, T., 1994. Reconstitution of the DNA base excision-repair pathway. Current biology: CB, 4(12), pp.1069-1076.

Drohat, A. \& Maiti, A., 2014. Mechanisms for enzymatic cleavage of the Nglycosidic bond in DNA. Organic \& Biomolecular Chemistry, pp.8367-8378. Available

at: http://pubs.rsc.org/en/Content/ArticleLanding/2014/OB/C4OB01063A.

Ely, B., 1991. Genetics of Caulobacter crescentus. Methods in enzymology, 204, pp.372-384.

Evinger, M. \& Agabian, N., 1977. Envelope associated nucleoid from Caulobacter crescentus stalked and swarmer cells. Journal of Bacteriology, 132(1), pp.294301.

Frederico, L.A., Kunkel, T.A. \& Shaw, B.R., 1990. A sensitive genetic assay for the detection of cytosine deamination: determination of rate constants and the activation energy. Biochemistry, 29(10), pp.2532-2537.

Friedberg, E., 2003. DNA damage and repair. Nature, 421, p.436-440.

Fromme, J.C., Banerjee, A. \& Verdine, G.L., 2004. DNA glycosylase recognition and catalysis. Current Opinion in Structural Biology, 14(1), pp.43-49.

Fuchs, R.P. \& Fujii, S., 2013. Translesion DNA synthesis and mutagenesis in prokaryotes. Cold Spring Harbor Perspectives in Biology, 5(12).

Galhardo, R.S. et al., 2005. An SOS-regulated operon involved in damageinducible mutagenesis in Caulobacter crescentus. Nucleic Acids Research, 33(8), pp.2603-2614.

Galhardo, R.S. et al., 2009. DinB upregulation is the sole role of the SOS response in stress-induced mutagenesis in Escherichia coli. Genetics, 182(1), pp.55-68.

Garibyan, L. et al., 2003. Use of the rpoB gene to determine the specificity of base substitution mutations on the Escherichia coli chromosome. DNA Repair, 2(5), pp.593-608.

Glover, B.P. \& McHenry, C.S., 2001. The DNA polymerase III holoenzyme: An asymmetric dimeric replicative complex with leading and lagging strand polymerases. Cell, 105(7), pp.925-934.

Goodman, M.F., 2002. Error-prone repair DNA polymerases in prokaryotes and 
eukaryotes. Annual review of biochemistry, 71(1), pp.17-50. Available at: http://www.annualreviews.org/doi/abs/10.1146/annurev.biochem.71.083101.124 707\nhttp://www.ncbi.nlm.nih.gov/pubmed/12045089.

Goodman, M.F. et al., 2016. Insights into the complex levels of regulation imposed on Escherichia coli DNA polymerase V. DNA Repair.

Gutierrez, A. et al., 2013. $\beta$-lactam antibiotics promote bacterial mutagenesis via an RpoS-mediated reduction in replication fidelity. Nature communications, 4, p.1610.

Available

at: http://www.ncbi.nlm.nih.gov/entrez/query.fcgi?db=pubmed\&cmd=Retrieve\&dopt $=$ AbstractPlus\&list_uids=23511474lnhttp://www. nature.com/ncomms/journal/v4/ n3/full/ncomms2607.html.

Hall, B.M. et al., 2009. Fluctuation analysis CalculatOR: a web tool for the determination of mutation rate using Luria-Delbruck fluctuation analysis. Bioinformatics (Oxford, England), 25(12), pp.1564-1565.

Hanahan, D., 1983. Studies on transformation of Escherichia coli with plasmids. Journal of Molecular Biology, 166(4), pp.557-580.

Hershberg, R. \& Petrov, D.A., 2010. Evidence that mutation is universally biased towards AT in bacteria. PLoS Genetics, 6(9).

Hildebrand, F., Meyer, A. \& Eyre-Walker, A., 2010. Evidence of selection upon genomic GC-content in bacteria. PLoS Genetics, 6(9).

Ippoliti, P.J. et al., 2012. Multiple strategies for translesion synthesis in bacteria. Cells, 1(4), pp.799-831. Available at: http://www.pubmedcentral.nih.gov/articlerender.fcgi?artid=3901139\&tool=pmce ntrez\&rendertype $=$ abstract.

Jacobs Jr., W.R. et al., 1989. Development of genetic systems for the mycobacteria. Acta Leprol, 7 Suppl 1, pp.203-207.

Janion, C., 2008. Inducible SOS response system of DNA repair and mutagenesis in Escherichia coli. International Journal of Biological Sciences, 4(6), pp.338-344.

Jarosz, D.F. et al., 2006. A single amino acid governs enhanced activity of DinB DNA polymerases on damaged templates. Nature, 439(7073), pp.225-8. Available at: http://www.ncbi.nlm.nih.gov/pubmed/16407906.

Jarosz, D.F. et al., 2007. Y-family DNA polymerases in Escherichia coli. Trends in Microbiology, 15(2), pp.70-77.

Jones, M.E., Thomas, S.M. \& Rogers, A., 1994. Luria-Delbruck fluctuation experiments: Design and analysis. Genetics, 136(3), pp.1209-1216.

Kana, B.D. et al., 2010. Role of the DinB homologs Rv1537 and Rv3056 in Mycobacterium tuberculosis. Journal of Bacteriology, 192(8), pp.2220-2227.

Kato, T. \& Shinoura, Y., 1977. Isolation and characterization of mutants of Escherichia coli deficient in induction of mutations by ultraviolet light. Molecular \& general genetics: MGG, 156(2), pp.121-131.

Kelman, Z. \& O'Donnell, M., 1995. DNA polymerase III holoenzyme: structure and function of a chromosomal replicating machine. Annual review of biochemistry, 64, pp.171-200. 
Kenyon, C.J. \& Walker, G.C., 1980. DNA-damaging agents stimulate gene expression at specific loci in Escherichia coli. Proceedings of the National Academy of Sciences of the United States of America, 77(5), pp.2819-2823.

Kim, S.R. et al., 1997. Multiple pathways for SOS-induced mutagenesis in Escherichia coli: an overexpression of $\operatorname{dinB} / \mathrm{din} P$ results in strongly enhancing mutagenesis in the absence of any exogenous treatment to damage DNA. Proceedings of the National Academy of Sciences of the United States of America, 94(25), pp.13792-7. Available at: http://www.ncbi.nlm.nih.gov/pubmed/9391106 Inhttp://www.pubmedcentral.nih.g ov/articlerender.fcgi?artid=PMC28386.

Kirby, T.W. et al., 2006. Structure of the Escherichia coli DNA polymerase III epsilon-HOT proofreading complex. The Journal of biological chemistry, 281(50), pp.38466-38471.

Kokoska, R.J. et al., 2002. Low fidelity DNA synthesis by a $Y$ family DNA polymerase due to misalignment in the active site. Journal of Biological Chemistry, 277(22), pp.19633-19638.

Kurthkoti, K. \& Varshney, U., 2011. Base excision and nucleotide excision repair pathways in mycobacteria. Tuberculosis, 91(6), pp.533-543.

Laub, M.T., Shapiro, L. \& McAdams, H.H., 2007. Systems biology of Caulobacter. Annual review of genetics, 41, pp.429-441. Available at: http://eutils.ncbi.nlm.nih.gov/entrez/eutils/elink.fcgi?dbfrom=pubmed\&id=180763 30\&retmode=ref\&cmd=prlinks $\backslash$ npapers3://publication/doi/10.1146/annurev.gene t.41.110306.130346.

Lee, D.H. et al., 2015. A structural determinant in the uracil DNA glycosylase superfamily for the removal of uracil from adenine/uracil base pairs. Nucleic Acids Research, 43(2), pp.1081-1089.

Lewis, L.K. et al., 1994. Identification of high affinity binding sites for LexA which define new DNA damage-inducible genes in Escherichia coli. Journal of molecular biology, 241(4), pp.507-23. Available at: http://www.sciencedirect.com/science/article/pii/S0022283684715282.

Lindahl, T., 1993. Instability and decay of the primary structure of DNA. Nature, 362(6422), pp.709-715.

Livingston, D.M., Hinkle, D.C. \& Richardson, C.C., 1975. Deoxyribonucleic acid polymerase III of Escherichia coli. Purification and properties. The Journal of biological chemistry, 250(2), pp.461-469.

Lutsenko, E. \& Bhagwat, A.S., 1999. The role of the Escherichia coli mug protein in the removal of uracil and 3,N4-ethenocytosine from DNA. Journal of Biological Chemistry, 274(43), pp.31034-31038.

Marks, M.E. et al., 2010. The genetic basis of laboratory adaptation in Caulobacter crescentus. Journal of Bacteriology, 192(14), pp.3678-3688.

Martins-Pinheiro, M., Marques, R.C. \& Menck, C.F., 2007. Genome analysis of DNA repair genes in the alpha proteobacterium Caulobacter crescentus. BMC Microbiology, 7, p.17.

McAdams, H.H. \& Shapiro, L., 2009. System-level design of bacterial cell cycle 
control. FEBS Letters, 583(24), pp.3984-3991.

McAdams, H.H. \& Shapiro, L., 2011. The architecture and conservation pattern of whole-cell control circuitry. Journal of Molecular Biology, 409(1), pp.28-35.

McHenry, C.S., 1982. Purification and characterization of DNA polymerase III'. Identification of tau as a subunit of the DNA polymerase III holoenzyme. The Journal of biological chemistry, 257(5), pp.2657-63. Available at: http://www.ncbi.nlm.nih.gov/pubmed/7037770.

McKenzie, G.J. et al., 2001. SOS mutator DNA polymerase IV functions in adaptive mutation and not adaptive amplification. Molecular Cell, 7(3), pp.571579.

McKenzie, G.J. et al., 2003. The dinB operon and spontaneous mutation in Escherichia coli. Journal of Bacteriology, 185(13), pp.3972-3977.

Mckenzie, G.J. et al., 2003. The dinB Operon and Spontaneous Mutation in Escherichia coli The dinB Operon and Spontaneous Mutation in Escherichia coli. Journal of Bacteriology, 185(13), pp.3972-77.

Murli, S. et al., 2000. A role for the umuDC gene products of Escherichia coli in increasing resistance to DNA damage in stationary phase by inhibiting the transition to exponential growth. Journal of Bacteriology, 182(4), pp.1127-1135. Nakabachi, A. et al., 2006. The 160-kilobase genome of the bacterial endosymbiont Carsonella. Science (New York, N.Y.), 314(5797), p.267.

Nierman, W.C. et al., 2001. Complete genome sequence of Caulobacter crescentus. Proceedings of the National Academy of Sciences of the United States of America, 98(7), pp.4136-41. Available at: http://www.pubmedcentral.nih.gov/articlerender.fcgi?artid=31192\&tool=pmcentr ez\&rendertype $=$ abstract.

Oh, T.J., Lee, C.W. \& Kim, I.G., 1999. The damage-inducible (din) genes of Escherichia coli are induced by various genotoxins in a different way. Microbiological research, 154(2), pp.179-183. Available at: http://dx.doi.org/10.1016/S0944-5013(99)80012-3.

Ohmori, H. et al., 2001. The Y-family of DNA Polymerases. Molecular Cell, 8(1), pp.7-8.

Olinski, R., Jurgowiak, M. \& Zaremba, T., 2010. Uracil in DNA-Its biological significance. Mutation Research - Reviews in Mutation Research, 705(3), pp.239-245.

Onrust, R. et al., 1995. Assembly of a chromosomal replication machine: Two DNA polymerases, a clamp loader, and sliding clamps in one holoenzyme particle. I. Organization of the clamp loader. Journal of Biological Chemistry, 270(22), pp.13348-13357.

Opperman, T., Murli, S. \& Walker, G.C., 1996. The genetic requirements for umuDC-mediated cold sensitivity are distinct from those for SOS mutagenesis. Journal of Bacteriology, 178(15), pp.4400-4411.

Panigrahi, G.B. \& Walker, I.G., 1990. The N2-guanine adduct but not the C8guanine or N6-adenine adducts formed by 4-nitroquinoline 1-oxide blocks the 3'5' exonuclease action of T4 DNA polymerase. Biochemistry, 29(8), pp.2122- 
2126. Available at: http://www.ncbi.nlm.nih.gov/pubmed/2109634.

Pearl, L.H., 2000. Structure and function in the uracil-DNA glycosylase superfamily. Mutation Research - DNA Repair, 460(3-4), pp.165-181.

Pérez-Capilla, T. et al., 2005. SOS-independent induction of dinB transcription by $\beta$-lactam-mediated inhibition of cell wall synthesis in Escherichia coli. Journal of Bacteriology, 187(4), pp.1515-1518.

Prakash, S., Johnson, R.E. \& Prakash, L., 2005. Eukaryotic translesion synthesis DNA polymerases: specificity of structure and function. Annual review of biochemistry, 74, pp.317-353.

Sale, J.E., Lehmann, A.R. \& Woodgate, R., 2012. Y-family DNA polymerases and their role in tolerance of cellular DNA damage. Nature reviews. Molecular cell biology, 13(3), pp.141-52. Available at: http://www.pubmedcentral.nih.gov/articlerender.fcgi?artid=3630503\&tool=pmce ntrez\&rendertype=abstract.

Sanders, L.H. et al., 2011. Epistatic roles for pseudomonas aeruginosa muts and dinb (DNA pol iv) in coping with reactive oxygen species-induced DNA damage. PLOS ONE, 6(4).

Sargentini, N.J. \& Smith, K.C., 1985. Spontaneous mutagenesis: the roles of DNA repair, replication, and recombination. Mutation Research/Reviews in Genetic Toxicology, 154(1), pp.1-27.

Sarkar, S., Ma, W.T. \& Sandri, G.H., 1992. On fluctuation analysis: a new, simple and efficient method for computing the expected number of mutants. Genetica, 85(2), pp.173-179.

Sartori, A.A. et al., 2002. A novel uracil-DNA glycosylase with broad substrate specificity and an unusual active site. EMBO Journal, 21(12), pp.3182-3191.

Schormann, N., Ricciardi, R. \& Chattopadhyay, D., 2014. Uracil-DNA glycosylases - Structural and functional perspectives on an essential family of DNA repair enzymes. Protein Science, 23(12), pp.1667-1685.

Simon, R., Priefer, U. \& Puhler, A., 1983. A broad host range mobilization system for in vivo genetic-engineering - transposon mutagenesis in gram-negative bacteria. Nature Biotechnology, 1.

Sloane, D.L., Goodman, M.F. \& Echols, H., 1988. The fidelity of base selection by the polymerase subunit of DNA polymerase III holoenzyme. Nucleic acids research, 16(14A), pp.6465-6475.

Smith, K.C., 1992. Spontaneous mutagenesis: Experimental, genetic and other factors. Mutation Research/Reviews in Genetic Toxicology, 277(2), pp.139-162. Studwell-Vaughan, P.S. \& O'Donnell, M., 1991. Constitution of the twin polymerase of DNA polymerase III holoenzyme. Journal of Biological Chemistry, 266(29), pp.19833-19841.

Thanbichler, M., Iniesta, A.A. \& Shapiro, L., 2007. A comprehensive set of plasmids for vanillate - And xylose-inducible gene expression in Caulobacter crescentus. Nucleic Acids Research, 35(20).

Traut, T.W., 1994. Physiological concentrations of purines and pyrimidines. Molecular and cellular biochemistry, 140(1), pp.1-22. 
Wagner, J. et al., 1999. The dinB gene encodes a novel E. coli DNA polymerase, DNA pol IV, involved in mutagenesis. Molecular Cell, 4(2), pp.281-286.

Walsh, J.M., Hawver, L.A. \& Beuning, P.J., 2011. Escherichia coli Y family DNA polymerases. Front Biosci (Landmark Ed), 16, pp.3164-3182. Available at: http://www.ncbi.nlm.nih.gov/pubmed/21622227.

Warner, D.F. et al., 2010. Essential roles for imuA'- and imuB-encoded accessory factors in DnaE2-dependent mutagenesis in Mycobacterium tuberculosis. Proceedings of the National Academy of Sciences of the United States of America, 107(29), pp.13093-13098.

Warren, J.J., Forsberg, L.J. \& Beese, L.S., 2006. The structural basis for the mutagenicity of $O^{6}$-methyl-guanine lesions. Proceedings of the National Academy of Sciences of the United States of America, 103(52), pp.19701-6. Available at: http://www.pnas.org/content/103/52/19701.abstract.

Waters, L.S. et al., 2009. Eukaryotic translesion polymerases and their roles and regulation in DNA damage tolerance. Microbiology and molecular biology reviews : MMBR, 73(1), pp.134-154.

West, L., Yang, D. \& Stephens, C., 2002. Use of the Caulobacter crescentus genome sequence to develop a method for systematic genetic mapping. Journal of Bacteriology, 184(8), pp.2155-2166.

$\mathrm{Wu}, \mathrm{H}$. et al., 2012. On the molecular mechanism of GC content variation among eubacterial genomes. Biology Direct, 7(1), p.2.

Zhao, X. et al., 2007. GC content variability of eubacteria is governed by the pol III ?? subunit. Biochemical and Biophysical Research Communications, 356(1), pp.20-25.

Zhigang, W., Smith, D.G. \& Mosbaugh, D.W., 1991. Overproduction and characterization of the uracil-DNA glycosylase inhibitor of bacteriophage PBS2. Gene, 99(1), pp.31-37. 